\title{
Symptoms of Musculoskeletal Disorders in Firefighter Worker in Brazil
}

\section{Felipe RAS*, Ferraz MCM, Machado LA, Oliveira LAS, Gondo FLB and Quemelo PRV}

Department of Physiotherapy, Sao Camilo University Center, Brazil

*Corresponding author: Felipe RAS, Department of Physiotherapy, Sao Camilo

University Center, Sao Paulo, Ave. Nazare, N. 1501, Sao Paulo, Brazil, Tel: 5698742666; Email: renata.as.felipe@gmail.com

\section{Research Article}

Volume 2 Issue 4

Received Date: July 16, 2018

Published Date: August 02, 2018

DOI: $10.23880 /$ eoij-16000169

\section{Abstract}

Fireman's labor activity requires situations of extreme physical demand and few studies are directed at this class of workers. The aim of this study was to identify the musculoskeletal disorders (MSD) symptoms in firefighter workers and to and verify the correlation of MSD prevalence with age and working time. Socio demographic were collected and the Nordic Questionnaire was used to verify the MSD prevalence. In Group A, 91\% of workers reported MSD symptoms for the last 6 months or in the last 7 days, with the low back region being the most affected? In Group B, 80\% of workers reported MSD symptoms in the last 6 months or the last 7 days. No significant difference was observed between the groups considering MSD prevalence with working time exposure and age of worker. In conclusion, most of the fireman reported some type of MSD symptoms (89\%); low back pain was the most body region affected. Work time factor and age did not influence the MSD prevalence. The results of the present study point to the need for interventions for this group of workers with the aim of reducing the MSD prevalence, regardless of working time exposure and age of worker.

Keywords: Cumulative Trauma Disorders; Workers; Musculoskeletal Pain; Low Back Pain

\section{Highlights}

MSD prevalence is high in firefighters, Low back pain is the most common complaint, Working time and the worker's age did not influence the prevalence of MSD, Regardless of working time and the worker's age preventive measures are necessary to reduce MSD

\section{Introduction}

Fireman's labor activity is intended to protect life, the environment and property. During these actions, professionals are subjected to situations of great physical effort, which involves agility, flexibility, strength, endurance and coordination. The firefighter's activity also requires emotional and mental balance to make decisions, which requires great concentration and attention and can generate significant mental load during actions $[1,2]$. The firefighter routine involves several events aimed at prehospital care, rescue, fire fighting and technical visits [3]. The firefighter's work shift lasts for 24 hours, comprising an alert period in which they are in the barracks waiting for calls, which increases the stress and anxiety state of the worker [4]. Recent studies have shown the correlation 


\section{Ergonomics International Journal}

of stressed workers with the appearance of MSD in the spine, shoulders and other regions of the body due to the increased tension of the musculature [5-7].

The musculoskeletal system of the firefighter may suffer overloads from the physical demands during rescues and abrupt actions. In addition, it is necessary to consider the need to use PPE (personal protective equipment). The PPE are fundamental for the protection of the fireman, however, the use of it, generates overload in the musculoskeletal system of the worker [5]. Exposure to noise, high temperatures, incorrect postures, and incorrect biomechanical movements may also increase the chances of workers developing MSD symptoms. It is also worth mentioning the complexity and multifactorial causes involved in occupational diseases, such as genetics, sex, age and time of exposure to the activity [8]. In view of the above, and due to the few existing studies on the risks of musculoskeletal injuries in firefighters, the objective of this study was to identify the prevalence of musculoskeletal symptoms in workers of a fire brigade, as well as to verify the correlation of time in the corporation and age of workers with the prevalence of disorders.

\section{Methods}

This is an exploratory cross-sectional study. The study was conducted at a Fire Department in Sao Paulo, Brazil. The study was approved by the Ethics Committee review board (Ref. 2.136.041).

\section{Subjects}

Sampling was for convenience. All firefighters from Fire Department were invited to participate in the study. We included in the study $(n=27)$, firemen of both genders, present on the day of the interview and who were willing to respond to the questionnaires. Firefighters who were not part of the corporation under study or who were on vacation were excluded.

\section{Demographic and Musculoskeletal Disorders (MSD) Assessment}

The demographic and occupational data were collected using a brief questionnaire. We collected the professional characteristics in relation to the age, sex, time in Fire Department, participation in occurrences, main activities performed and their current health status.

To evaluate the MSD prevalence the Nordic Questionnaire was applied. The instrument addresses the body location of the complaint and how long these individuals have complained. The questionnaire is considered an easily applicable instrument, with $86 \%$ of the results presenting a corresponding clinical correlation. The Nordic Questionnaire responses have been found to have high reliability and validity (Kappa values: $0.83-1.0][9,10]$.

\section{Data and Statistical Analysis}

Data collection was done in three days because of changing work shifts. Initially, the subjects who agreed to participate in the study signed the Informed Consent Term. Subsequently, the questions on demographic and occupational data were applied, followed by the Nordic questionnaire.

For the analysis of the data, the participants $(n=27)$ were divided into two groups according to the working time (Group A $>5$ or Group B $<5$ years). The data were tabulated in the Excel 2010 program to obtain the mean, standard deviation, relative and absolute values. For the statistical analysis of inference, the variables in relation to the MSD prevalence were compared between groups, over 5 years of work, called Group A and below 5 years of work, called Group B using the Mann-whitney test. For the analysis of correlation between the variables of MSD prevalence and worker's age, the Spearman test was applied, considering that all the data did not present a normal distribution, by D'Agostino's test. All statistical analysis was performed with 5\% significance using Graph Pad Prism 5.0 software.

\section{Results}

The results for the MSD symptoms showed that 20 (91\%) of the workers reported some type of physical discomfort in the last 6 months or in the last 7 days for Group A, with the low back region being the most affected. The Group B, 4 (80\%) of the workers reported some type of MSD symptoms in the last 6 months or in the last 7 days, being the regions of the shoulders and knees most affected (Table 1).

\begin{tabular}{|c|c|c|c|c|c|c|c|c|c|c|}
\hline \multirow{2}{*}{ Region } & \multicolumn{4}{|c|}{ Group A (n=22) } & \multicolumn{4}{c|}{ Group B (n=5) } \\
\cline { 2 - 10 } & \multicolumn{2}{|c|}{$\mathbf{7}$ days } & \multicolumn{3}{|c|}{$\mathbf{6}$ months } & \multicolumn{2}{c|}{ 7 days } & \multicolumn{2}{|c|}{ months } \\
\cline { 2 - 10 } & $\mathbf{N}$ & $\mathbf{\%}$ & & $\mathbf{N}$ & $\mathbf{\%}$ & $\mathbf{N}$ & $\mathbf{\%}$ & & $\mathbf{N}$ & $\mathbf{\%}$ \\
\hline Neck & 3 & 14 & & 6 & 27 & 0 & 0 & & 0 & 0 \\
\hline Shoulders & 4 & 18 & & 5 & 22 & 1 & 20 & 2 & 40 \\
\hline
\end{tabular}




\section{Ergonomics International Journal}

\begin{tabular}{|c|c|c|c|c|c|c|c|c|c|c|}
\hline Upper Back & 3 & 13 & & 7 & 31 & 0 & 0 & & 1 & 20 \\
\hline Elbows & 0 & 0 & & 1 & 5 & 0 & 0 & & 0 & 0 \\
\hline Lower back & 5 & 23 & & 11 & 50 & 1 & 20 & & 1 & 20 \\
\hline Wrists/hands & 0 & 0 & & 1 & 5 & 0 & 0 & & 1 & 20 \\
\hline Hips/thighs & 1 & 5 & & 3 & 14 & 0 & 0 & 0 & 0 \\
\hline Knees & 2 & 9 & & 8 & 36 & 1 & 20 & & 2 & 40 \\
\hline Ankles/feet & 2 & 9 & & 9 & 41 & 0 & 0 & & 0 & 0 \\
\hline
\end{tabular}

Table 1: Distribution of musculoskeletal disorders related to the regions of the body in the last 7 days and in the last 6 months for both groups.

Although the results of the comparison between Group A $(2.91 \pm 1.99)$ showed a greater tendency for MSD prevalence, when compared with Group B $(1.80 \pm 1.30)$, the findings were not statistically significant $(\mathrm{p}=0.239)$, as shown in figure 1.

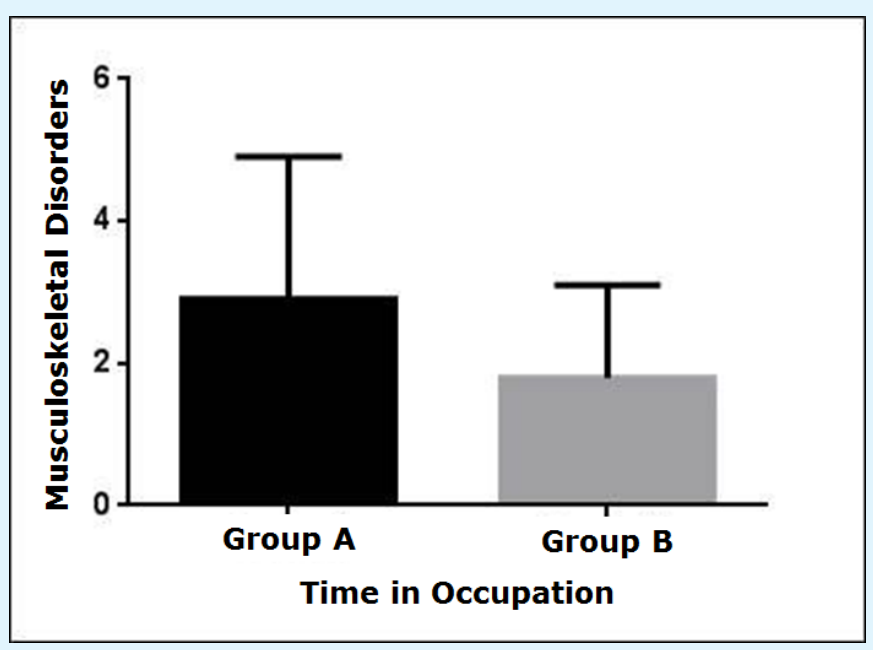

Figure 1: Comparison between the groups for the values (mean and standard deviation) of musculoskeletal disorders by the Nordic questionnaire $(\mathrm{p}=0.239)$.

The figure 2 shows the dispersion of the values of the correlation between MSD symptoms and age of the workers by Nordic questionnaire. For Group A, the analysis presented a low correlation $(r=-0.21)$ and did not show significance $(p=0,348)$.For Group B, the analysis presented a negative correlation $(r=-0.89, \mathrm{p}=$ 0.001).
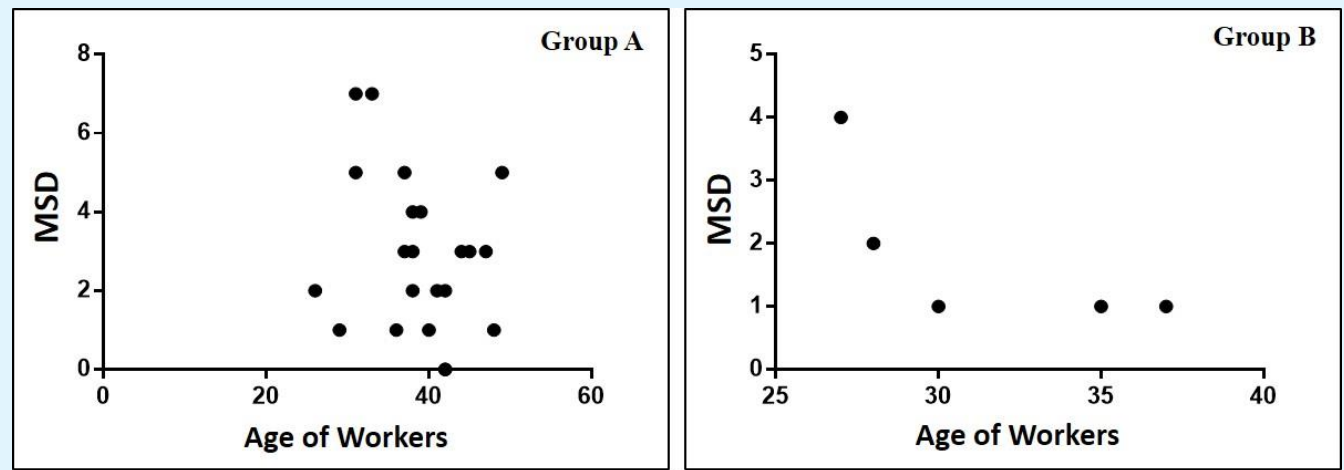

Figure 2: It shows the dispersion of the values between the age of the workers and the number of musculoskeletal disorders by the Nordic questionnaire for both groups. 


\section{Ergonomics International Journal}

\section{Discussion}

There is little specific scientific evidence about MSD symptoms in firefighters. Recent study has shown that a large part of the fireman's' exits of the work is related to musculoskeletal and connective tissue disorders [11]. According to this information, the results of the present study demonstrate a high prevalence of musculoskeletal disorders (89\%), especially in the last 6 months, which indicates a chronic problem in workers and may explain the importance of musculoskeletal disorders in the work of firefighters. Similar results were found in the study by Marques [12], who observed that $70 \%$ of the firefighters presented some MSD symptom in the last year, with the low back region $(50 \%)$ being the most affected. In the present study, the low back region presented a higher prevalence of musculoskeletal symptoms (67\%), followed by the knee region (48\%) and ankle (40\%), considering the last 7 days and the last 6 months of both groups. This high prevalence of MSD pain in the low back region has also been described in another study with firefighter professionals [13] and described in military police officers interviewed [14]. MSD and low back pain are also published in other professions such as rubber tappers $[15,16]$. Usually musculoskeletal disorders, especially in the low back region, present multifactorial etiology, with both individual and work environment risk factors. Faced with this, individual risk factors need to be considered: age, gender, muscle imbalance, muscular strength and the presence of other pre-existing diseases. On the other hand, the risk factors of the work environment may be associated with incorrect movement and postures due to the work environment, working conditions of the equipment used, and the organization and execution of the activity [17]. Thus, a possible explanation for the high prevalence of musculoskeletal symptoms found in the present study, including the low back pain, knees and ankles, may be related to individual factors and working conditions, due to the constant overloads imposed by the PPE, transport of patients and transportation of equipment during the occurrences. Other factors, such as stress level, overweight, as well as alteration in the proper synergism of the musculature due to the use of PPE and the time exposed in inappropriate positions are also risk factors for the onset of MSD symptoms [18-20].

Although not significant, another important result of the present study was a greater trend in the MSD prevalence in workers who are longer in the Fire Department, which corroborates the statement about the influence of the fireman's occupational activity on the high prevalence of disturbances. The correlation result of the present study did not demonstrate significant difference in relation to the MSD symptoms and age of workers for the firemen with more time in the corporation. The result for the group of firemen with less than five years in the corporation showed a negative and significant correlation in relation to MSD prevalence and age of workers. These findings may have been random and may be compromised due to the small number of participants in the present study. The age factor and time of exposure in the workplace are considered risk factors that should be considered. Although in the present study, the influence of these factors on the MSD prevalence was not observed. The findings of the present study may be a possible guideline for future work that may seek specific intervention to try to prevent the occurrence of these disorders, such as occupational kinesis therapy, improvements in PPE and other ergonomic interventions. The present study presents some limitations, mainly in relation to the number of participants. Other studies with large sample numbers should be performed to better understand the mechanisms involved in the onset of musculoskeletal disorders.

\section{Conclusion}

Most firemen reported some type of MSD symptom (89\%), with the low back region being the most affected. No statistical difference was observed between time of exposure and no significant correlation between age and MSD prevalence symptoms was observed. The results of this study point to the need for interventions for this group of workers with the aim of reducing the MSD prevalence in fire department workers, regardless of age or time of exposure to the work environment.

\section{References}

1. Natividade MR (2009) Vidas em risco: A Identidade profissional dos bombeiros militares. Psicol Soc 21(3): 411-420.

2. Vidotti HGM, Coelho VHM, Bertoncello D, Walsh IAP (2015) Qualidade de vida e capacidade para o trabalho de bombeiros. Fisioter Pesp 22(3): 231-238.

3. Brasil Ministério da Justiça (2013) Pesquisa perfil das instituições de segurança pública.

4. Monteiro JK, Maus D, Machado FR, Pesenti C, Bottega D, et al. (2007) Bombeiros: um olhar sobre a qualidade de vida no trabalho. Psicol cienc prof 27(3): 554-565.

5. Santos M, Almeida A (2016) Principais riscos e fatores de risco ocupacionais associados aos bombeiros, eventuais doenças profissionais e 


\section{Ergonomics International Journal}

medidas de proteção recomendadas. Rev Port Saúde Ocup.

6. Almeida LB, Vieira ER, Zaia JE, Santos BMO, Lourenço ARV, et al. (2017) Musculoskeletal disorders and stress among footwear industry workers. Work 56(1): 67-73.

7. Vieira ER, Serra MVGB, Almeida LB, Villela WV, Scalon JD, et al. (2015) Symptoms and risks for musculoskeletal disorders among male and female footwear industry workers. International Journal of Industrial Ergonomics 48: 110-116.

8. Kumar S (2001) Theories of musculoskeletal injury causation. Ergonomics 44(1): 17-47.

9. Barros ENC, Alexandre NMC (2003) Cross-Cultural Adaptation of the Nordic Musculoskeletal Questionnaire. International Nursing Review 50(2): 101-108.

10. Pinheiro FA, Tróccoli BT, Carvalho CV (2002) Validity of the Nordic Musculoskeletal Questionnaire as morbidity measurement tool. Rev Saúde Pública 36(3): 307-312.

11. Pires LAA, Vasconcellos LCF, Bonfatti RJ (2005) Bombeiros militares do Rio de Janeiro: uma análise dos impactos de suas atividades de trabalho sobre sua saúde. Saúde debate 41(113): 577-590.

12. Marques CRCS, Lira MCC, Junior BJSJ, CRUS SL, Lima BRDA, et al. (2014) Avaliação de riscos ergonômicos relacionados à atividade de bombeiros militares. Revenferm UFPE 8(9): 3082-3089.

13. Silva IN, Vieira CSC, Prado ERA, Rodrigues JE (2011) Prevalência de lombalgia em socorristas de resgate do corpo de bombeiros militar de Alagoas. Rev Inspirar Mov Saúde 3(1): 26-30.

14. Trindade APNT, Oliveira LCN, Santos BMO, Oliveira FB, Quemelo PRV (2015) Symptoms of musculoskeletal disorders among police officers. Arq Ciênc Saúde 22(2): 42-45.

15. Meksawi S, Tangtrakulwanich B, Chongsuvivatwong V (2018) Musculoskeletal Disorder (MSDs) and Rapid Upper Limb Assessment (RULA) Scoring Among Rubber Tappers. Ergonomics Int J 2(6): 000163.

16. Meksawi S, Tangtrakulwanich B, Chongsuvivatwong $\mathrm{V}$ (2018) Structural Loading of the Lower Lumbar Area in Different Level of Rubber Tapping. Ergonomics Int J 2(6): 000161.

17. Junior MH, Goldenfum MA, Siena C (2010) Lombalgia ocupacional. Rev Assoc Med Bras 56(5): 583-589.

18. Noriega-elío M, Soto AB, Martínez OS, Navarro MO, Flores CC (2005) La polémica sobre las lumbalgias y surelación com eltrabajo: estudio retrospectivo en trabajadores con invalidez. Cad Saúde Pública 21(3): 887-897.

19. Queiroga MR, Ferreira AS (2005) Ocorrência de dor na coluna vertebral em motoristas de ônibus e bombeiros militares. Cient Ciênc Biol Saúde 7(1): 2126.

20. Silva MC, Fassa AG, Domingues MR, Kribel D (2007) Knee pain and associated occupational factors: a systematic review. Cad Saúde Pública 23(8): 17631775. 